\title{
Environmental tracers and indicators bringing together groundwater, surface water and groundwater-dependent ecosystems: importance of scale in choosing relevant tools
}

\author{
G. Bertrand - D. Siergieiev - P. Ala-Aho • \\ P. M. Rossi
}

Received: 25 April 2013/Accepted: 8 December 2013

(C) Springer-Verlag Berlin Heidelberg 2013

\begin{abstract}
Groundwater-surface water (GW-SW) interactions cover a broad range of hydrogeological and biological processes and are controlled by natural and anthropogenic factors at various spatio-temporal scales, from watershed to hyporheic/hypolentic zone. Understanding these processes is vital in the protection of groundwater-dependent ecosystems increasingly required in water resources legislation across the world. The use of environmental tracers and indicators that are relevant simultaneously for groundwater, surface water and biocenoses-biotope interactions constitutes a powerful tool to succeed in the management task. However, tracer type must be chosen according to the scale of interest and tracer use thus requires a good conceptual understanding of the processes to be evaluated. This paper reviews various GWSW interaction processes and their drivers and, based on available knowledge, systemises application of conservative tracers and semi-conservative and reactive environmental indicators at different spatial scales. Biocenoses-
\end{abstract}

\footnotetext{
G. Bertrand

Instituto de Geociências, CEPAS (Groundwater Research

Center), University of São Paulo, Rua do lago 562,

São Paulo, Brazil

e-mail: guillaume.bertrand@email.com

D. Siergieiev $(\bowtie)$

Luleå University of Technology, 97187 Luleå, Sweden

e-mail: dmytro.siergieiev@1tu.se

P. Ala-Aho · P. M. Rossi

Water Resources and Environmental Engineering Laboratory,

Department of Process and Environmental Engineering,

University of Oulu, PO Box 4300, 90014 Oulu, Finland

e-mail: pertti.ala-aho@oulu.fi

P. M. Rossi

e-mail: pekka.rossi@oulu.fi
}

biotopes relationships are viewed as a possible transition tool between scales. Relation between principal application of the environmental tracers and indicators, examples and guidelines are further proposed for examining GW-SW interactions from a hydrogeological and biological point of view by demonstrating the usability of the tracers/indicators and providing recommendations for the scientific community and decision makers.

Keywords Groundwater-dependent ecosystems . Environmental tracers $\cdot$ Hyporheic zone $\cdot$ GW-SW interaction $\cdot$ Indicators

\section{Introduction}

It is now broadly recognised that global and local anthropogenic activities are severely threatening groundwaterdependent ecosystems (GDEs) in general and groundwater-surface water (GW-SW) interfaces in particular (Hancock 2002). Abundant urban contaminants, agriculture (Soulsby et al. 2001; Pacioni et al. 2010), industry (Engelhardt et al. 2011), mining activities (Gandy et al. 2007; Smerdon et al. 2012), road and tunnel construction (Kværner and Snilsberg 2008), forestry (Rossi et al. 2012), hydropower regulation (Renöfält et al. 2010), and channelization (Petalas 2013) exert a pronounced impact on water systems, and pose a risk to the related ecosystems. Alteration of water quantity and quality threatens the function of hyporheic/hypolentic zone (HZ), that corresponds to the space below the stream/lake bed (Winter 2001) where GW and SW mix, and exposes productive riparian zones to the risk of degradation and possible disappearance. Consequently, recent advancements in environmental legislation, e.g. the Water Framework Directive 
2000/60/EC (Council of the European Community 2000), Swiss Water Protection Ordinance (GSchV 1998), Western Australian Guidance for the Assessment of Environmental Factors (EPA 2003) and the USGS National Water Quality Assessment Program (Leahy et al. 1990) demand a more integrated approach where GDEs are considered in a common surface water and groundwater management system. Implementation of these directives requires a deeper understanding of the connectivity between groundwater, surface water and related biocenoses to assess whether threats to these pose a risk to GDEs (e.g. Kløve et al. 2011a; Bertrand et al. 2012a, b). Among the environmental services provided by GDEs are a barrier function between terrestrial and aquatic ecosystems, control of hydrological and geochemical fluxes, moderation of surface water temperature and attenuation of pollutants by dilution or biodegradation. GDEs also serve as a habitat for nutrient cycling, spawning and nesting areas, etc. (Danielopol et al. 2004; Boulton et al. 2008; Tomlinson and Boulton 2008; Bertrand et al. 2012a).

For integration of GDEs into water management, knowledge of the principles governing flow and mass exchange between surface water and aquifers is vital in assessment of ecosystem function and structure and in planning ecosystem restoration (Kløve et al. 2011a; Smerdon et al. 2012; Grathwohl et al. 2013). In addition, practical water management involves dealing with conceptual and technical constraints for such assessments (e.g. Kløve et al. 2011b). From a conceptual point of view, GW-SW interactions cover a large array of hydrological, physico-chemical (solute and heat) and biogeochemical (transformation, precipitation, sorption, degradation) interactions which need to be distinguished at various scales (e.g. Ward et al. 1998; Bertrand et al. 2012a). In parallel, evaluation of the character of GW-SW interactions requires different techniques that should be as financially accessible as technically possible, both in developing countries and in developed countries in economic recession (Kløve et al. in press).

Moreover, the scientific community has to bring together these interdisciplinary problems within biological and hydrogeological processes, which in most cases are considered separately, although requiring similar investigation tools. Biologists and ecologists usually define GDEs by environmental conditions (e.g. water availability, thermal and nutritive conditions) that influence the health and behaviour of individuals or communities, i.e. how biotope variability affects biocenoses. In contrast, hydrologists and hydrogeologists view SW and GW as vectors characterised by flux variability (e.g. discharge, heat and chemical fluxes) that depends on land use, climate and hydrogeological conditions.
In this context, this paper aims to review possible uses of selected natural tracers or so-called environmental indicators harbouring a merged biological and hydrological interest to assess GW-SW connectivity, with the perspective of assisting in the design of tools usable by scientists and managers to diagnose the current status of GDEs in an integrated approach. Other papers reviewing the GW-SW interaction assessment methods, which are numerous, and their limits, already exist (e.g. Kalbus et al. 2006; Cook 2012), therefore, this paper mainly focuses on tracing methods that are also suitable for biological/ecological characterisation of the GW-SW interface.

The concepts underlying GW-SW interactions and the types and properties of natural tracers or indicators relevant in both ecological and hydrological perspectives are briefly presented. In this paper, the term "tracer" defines nonreactive parameters that provide information on water sources, whereas "chemical or physico-chemical indicators" refer to parameters that carry signatures of processes along the flowpath, typically temperature and dissolved species. Biological indicators refer to living fauna and flora. It was assumed here that an accurate use of selected tracers and indicators can help formulate a conceptual model of GDEs, which is needed to illustrate the role of management in GDE protection and their sustainability. Application of natural tracers/indicators is viewed here for three different scales and the relationship between conservativeness of the parameters and application scale is examined.

\section{GW-SW interactions and ecological meaning at different scales}

Interactions between SW and GW are governed by hydrological and geometrical drivers at various scales (Kløve et al. 2011a; Bertrand et al. 2012a).

At the watershed scale, GW-SW interactions are mainly related to hydrological exchanges, i.e. whether a lake or a river gains or loses water through its bed. This is largely determined by the location of the surface water body with respect to local and regional groundwater flow systems (Toth 1963). From an ecological perspective, at the watershed scale, the main attribute of a water resource is the hydroperiod (Eamus et al. 2006; Hahn 2006), controlled by climate, catchment and aquifer internal geometry and land use (Alfaro and Wallace 1994). Therefore, the main features of GW-SW interaction at this scale are location of the recharge/discharge zones and amount of water involved in the interaction (e.g. Guggenmoss et al. 2011). At this scale, seasonal hydrological processes may affect the structure of biocenoses with a relatively long metabolism cycle, i.e. macrophytes (Bertrand et al. 2012a). 


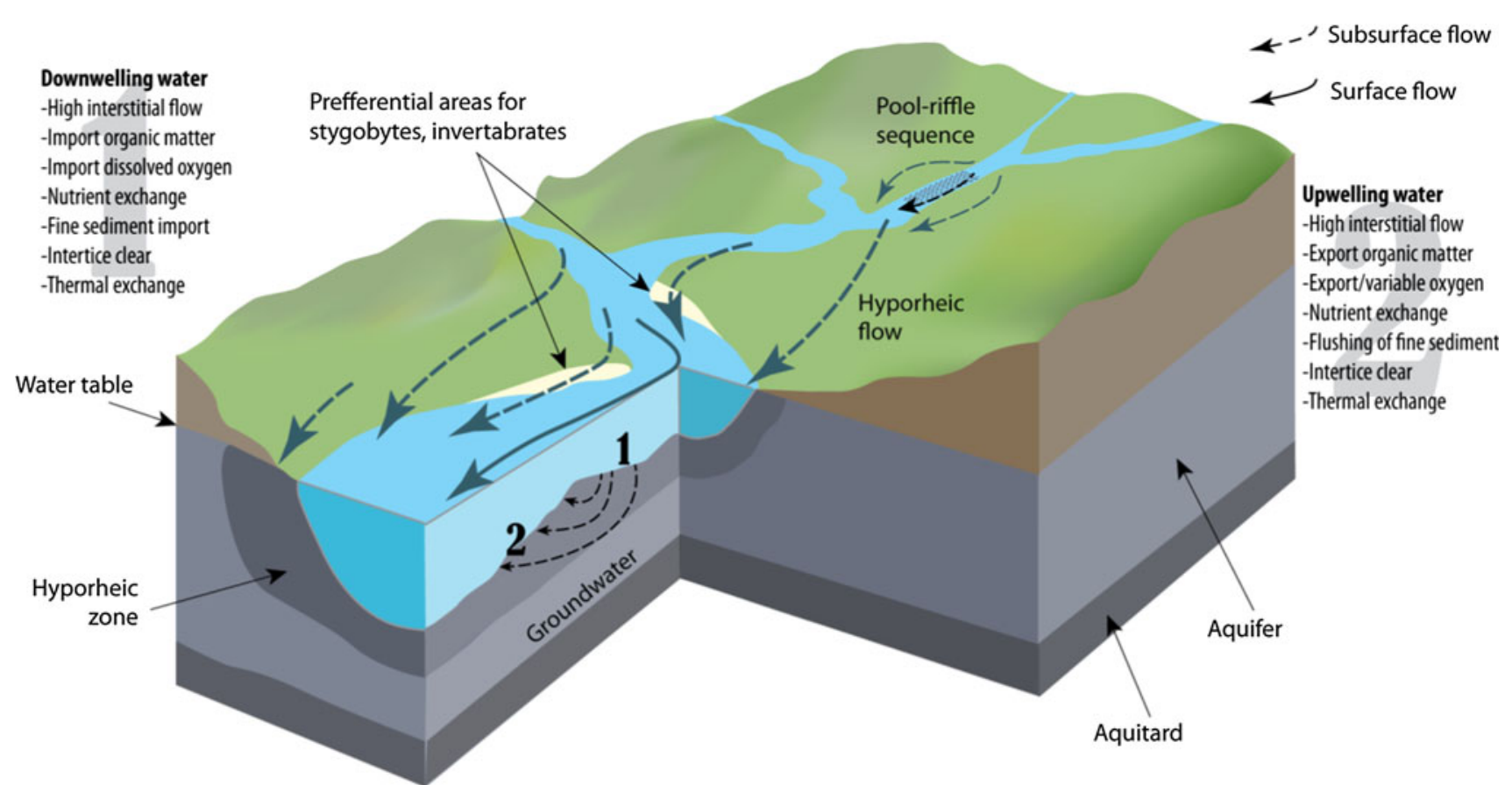

Fig. 1 Conceptual scheme of hyporheic zone (HZ) function at the streambed surface (adapted from Boulton et al. 2010; McCabe 2010; Bertrand et al. 2012a). Flows are controlled by streambed topography, distribution and particle size of sediments which influence hydraulic

At the reach scale (i.e. from tens of metres to kilometres), surface systems tend to exchange water with subsurface as a function of local hydraulic conductivity and hydraulic gradient between the channel and the adjacent aquifer (e.g. Boulton et al. 2010). Irregular bed profiles that result in rapids and pools induce local gradients and flow patterns at this scale (Winter et al. 1998). In lotic systems, upwelling and downwelling may be governed by river bed discontinuities, minor morphological irregularities, changes in the direction of flow (hydropeaking), and/or heterogeneities in hydraulic conductivity of the river bed (Fig. 1) (Brunke and Gonser 1997; Stonedahl et al. 2010; Bertrand et al. 2012a). At this scale, questions of the recharge/discharge zones are still valid, but the effects of heat and geochemical exchange (nutrients, dissolved oxygen, major ions) become important factors for biocenoses, e.g. stygophile and stygoxene fauna or fish eggs (Malcolm et al. 2004; Storey et al. 2004; Soulsby et al. 2009).

Consequently, at a scale of several metres, in which water exchange occurs within shallow $\mathrm{HZ}$ the above cited biocenoses will impact the highly dynamic parameters such as dissolved oxygen (DO), redox potential, dissolved organic carbon (DOC), and nitrogen speciation.

In this context, as GW-SW interactions may be hydrologically and biogeochemically dependent on the scale of interest and control GDEs functioning, the use of relevant conductivity and the extent of vertical hydraulic gradients. These patterns affect water fluxes and mass transport into and out of the HZ. Processes are shown with respect to the HZ

tracers/chemical indicators at relevant scale and the observation of related biocenoses create integrated knowledge of this exchange and of its ecological consequences.

\section{Use of tracers and indicators at the three conceptual scales}

Natural tracers allow identification of water origins and proportions of GW-SW mixing, whereas indicators carry signals from the geological, environmental, thermal and biological interactions along a flowpath (Güler and Thyne 2004; Kumar et al. 2009). These two domains are important to evaluate when studying the GW-SW interactions as well as their ecological consequences. A variety of chemical transformations that water may undergo along its flowpath requires a combined application of different tracing techniques.

The use of natural tracers implies that the mixing of the end-members has a distinctive physico-chemical, chemical or isotopic composition. Their robustness regarding the above discussed spatial and temporal scales is also a key point (Fig. 3). Prior knowledge about indicators reactivity is essential for comprehending complex water interactions in a landscape. Further, the applicability of environmental 
parameters is reviewed and exemplified below to establish a typology of methods according to the type of GW-SW interaction. The advantages and disadvantages associated with the usage of some environmental tracers and chemical indicators have previously been reviewed (Kalbus et al. 2006; Cook 2012) and are also glimpsed in this review.

The watershed scale

Assessment of hydrometric and conservative geochemical interactions

Tracers such as water itself (hydrometric techniques, i.e. water level and discharge measurements), stable isotopes (especially oxygen 18 and deuterium of the water molecule) and some dissolved water constituents have successfully been used to identify a GW-SW interaction type (i.e. gain/loss) and quantify this interaction (see the review by Kalbus et al. 2006). Numerous studies suggest that differences in water composition between neighbouring GW and SW bodies can be used to qualitatively or statistically infer their interactions (e.g. Taylor et al. 1989; Kumar et al. 2009) or, if water flux data are available, to estimate water fractions derived from different sources or end-members with distinct hydrochemistry (e.g. Schmidt et al. 2010).

The use of various parameters across watersheds often involves work with large datasets that have a wide spatial and temporal spread. In this context, multivariate methods such as hierarchical cluster analysis and principal components analysis are becoming increasingly popular, especially where the water flux data are not available. For instance, Güler and Thyne (2004) and Thyne et al. (2004) classified groundwater and surface water bodies at multiwatershed and single watershed scales, respectively, to identify localised areas of groundwater recharge and discharge. Kumar et al. (2009) utilised similar statistical methodologies, simultaneously classifying groundwater and surface water bodies based on their hydrochemical similarities, to specifically identify the flowpath of a contaminated groundwater baseflow to an urban area of the Yamuna River in India. Such datasets have even been utilised to individually classify groundwater and surface water at regional scale (e.g. Thyne et al. 2004; McNeil et al. 2005), but some recent studies have developed this approach by simultaneously classifying both groundwater and surface water into a similar hydrochemical facies to determine their interrelationships and degree of interaction (Guggenmoss et al. 2011). This involves a hypothesis that similarities in the hydrochemistry of groundwater and surface water may be a result of interactions between these compartments. In this perspective, Guggenmoss et al. (2011) were able to map GW-SW interaction types at the scale of the Wairarapa watershed, New Zealand, by determining the location of losing, gaining and neutral reaches.

When discharge is known, some of the major elements may be used for hydrograph separation and groundwater flowpath delineation (Hooper and Shoemaker 1986; Laudon and Slaymaker 1997; Stewart et al. 2007; Guggenmoss et al. 2011). Rossi et al. (2012) used variations in electrical conductivity, calcium and silica ion concentrations and fluxes to evaluate the relative contribution of a sandy aquifer and of its overlying peat layer into a headwater stream originating from Rokua esker. The significant difference in silica and calcium content, which was higher in groundwater from the sandy system, permitted to show that water in the stream originated from the sandy aquifer. In this context, the use of tracers and chemical indicators delineated 'pipe flow' channels and showed that the previously estimated low average hydraulic conductivity of peat layers does not necessarily indicate poor connectivity between a fen and groundwater as assumed in previous studies using only hydrological approaches. In terms of management of the connected GDEs, this study showed that the pipe flows are specific areas in which GW-SW connectivity requires reinsurance.

The above-mentioned techniques provide information about the direction, dynamics and quantity of GW-SW exchange. However, one needs to keep in mind that a number of other techniques exists to evaluate the GW-SW interactions at this scale which provide valuable complementary information and may be even required in many cases to obtain either a first insight of possible interaction areas or a quantitative evaluation of interaction. Residence time indicators such as radon-222 activity usually increase exponentially with time in groundwater, but decrease in surface water due to degassing processes (Hoehn and von Gunten 1989), recharge dating parameters like CFC's and SF6 (e.g. Cook et al. 2006; Cook 2012), $\delta^{18} \mathrm{O}$ and $\delta^{2} \mathrm{H}$ of water when SW and GW signatures are evidently different, provide information about fluxes and exchange dynamics (Kendall and Caldwell 1998; Négrel et al. 2003; Osenbrück et al. 2013; Mohammed et al. 2014), and may even help to distinguish the effect of anthropogenic activities (e.g. gravel excavation) on the watershed infiltration rate and related GDEs (Smerdon et al. 2012). In many cases, hydroecological evaluation of GW-SW interactions may require the use of such tools, that have not directly an impact on biological processes but that allow quantitative estimation of GW-SW interactions. Conceptual models exemplifying the use of these parameters and their limitations have been reviewed by Kalbus et al. (2006) and Cook (2012). 
As the concentrations of major elements in GW are highly dependent on both geological and land-use settings, these indicators are most suitable when the watershed geology and occupation are well known (Bencala et al. 1987; Laudon and Slaymaker 1997; Ala-aho et al. 2013). Some chemical data should be carefully used, especially during periods of high metabolism of the aquatic species in $\mathrm{SW}$, where precipitation of authigenic components that can have a direct impact on dissolved calcium and carbonate species may occur in the areas of algal productions (Meybeck 1998; Grosbois et al. 2001; Nimick et al. 2011). Therefore, a statistical comparison between GW and SW should account for seasonal biological processes (Négrel et al. 2003).

The approaches described above are based on the differences and/or similarities between SW and GW. Quantitative and temporal extent of the geochemical modifications resulting from their interaction changes over time and affects biocenoses located at the SW-GW interface (Bertrand et al. 2012a). Therefore, investigation of SW-GW interactions should involve biological community evaluations to precise the ecological consequences of this interaction. It would also permit to initiate the downscaling to the reach zone, provided that they could help to identify areas of GW-SW interactions with specific ecological values.

\section{Downscaling from watershed scale to reach scale: the macrophyte biodiversity}

Most of the chemical indicators discussed above, mainly major elements, may be viewed as nutrients from an ecological point of view and therefore have an impact on the biodiversity. The hardness of water along river reaches and repartition of given plant species can be directly related to each other, demonstrating the nutritive status of water (dystrophic, oligotrophic, mesotrophic, eutrophic or polytrophic; see Seddon 1972; Garbey et al. 2004). Combining hardness ratio (related to hydrochemical facies), total dissolved solids and conductivity, Haslam (1987) evaluated a favoured nutritive level for broadly spread macrophytes in European rivers. Thus, the land use and the buffering capacity of the bedrock and the surrounding soils may be considered as controls of the repartition and diversity of plant species in GDEs. Consistently, at the watershed scale, the analysis of diversity of macrophytes, which constitute the basis for trophic chains, allows evaluating the longterm nutritive role of GW, SW and their exchange. On this basis, typologies may be proposed to identify areas where groundwater strongly affects the hydroecological function of GW-SW interaction areas (Bertrand et al. 2012a; Table 1). The resulting classification system, done at the European scale, mainly deals with aquatic and hydrophytic vegetal biocenoses (biological indicators) settled on mineral interfaces, namely fluvisols, where redoximorphic features are common, or gleysols, where influences of groundwater are evident (reddish, brownish and yellowish colours) (Baize et al. 2009). These systems are extremely sensitive to hydrological modifications as for example specialisation of some charismatic plants (e.g. Chara sp.) to high water-calcium content. This typology permits a long-term evaluation of GW-SW interactions and thus their evolution (i.e. changes, impacts, risks etc.) by e.g. comparison between past, present and future flora diversity at the watershed scale. Nevertheless, the dynamic processes controlling these interactions are poorly constrained with these techniques. For example, a reach that gains groundwater and loses some surface water can be considered to be gaining, but even if the water balance is positive it does not mean that the reach cannot be flow-through (Fig. 2). Furthermore, a losing area may or may not be connected to the groundwater. These processes are ecologically meaningful for biocenoses, but can easily be overlooked by large-scale approaches. In this context, it may be necessary to downscale the investigations by focusing on more reactive hydroecological parameters at specific reach areas (Table 2).

To summarise, at the watershed scale, rather conservative chemical indicators and tracers in combination with stream hydrograph information are the key tools to understand the SW-GW interaction within a catchment, expose major sources, flowpath and fluxes. In parallel, the distribution of macrophytes along GW-SW interfaces reveals smaller scale interaction zones and may serve therefore a transitional step in downscaling, before studying the reach scale.

\section{The reach scale}

\section{Assessment of spatially and temporally variable physico-} chemical interactions

Exchange processes between streams and groundwater include downwelling of stream water into the sediment and its re-emergence further downstream (Boulton et al. 2010) (Fig. 1). Therefore, much of the water in a floodplain is repeatedly interacting with surface water. In this context, indicators which are able to reflect temporal patterns adapted to moderate scale processes are needed. These parameters should be sufficiently distinct in groundwater and surface water and well constrained at the scale of several to hundreds of metres.

Groundwater temperature, electrical conductivity (EC) and DOC are relatively stable throughout the year, in contrast to surface water, which is much more reactive to daily and seasonal hydrological variations (Shimada et al. 
Table 1 Systematic summary of the key processes related to GDEs and species that indicate type of GW-SW interaction

\begin{tabular}{|c|c|c|c|c|c|c|}
\hline & \multicolumn{2}{|c|}{ Aquifer-scale attributes } & $\begin{array}{c}\text { Emergence-scale } \\
\text { attributes }\end{array}$ & GDE denomination & \multicolumn{2}{|c|}{ Ecology } \\
\hline \multicolumn{7}{|c|}{ Hyporheic zone } \\
\hline & \multicolumn{3}{|c|}{ Characteristic } & & Indicative ecosociology & Indicative species \\
\hline & Hydrological & Chemical & Geomorphological & & & \\
\hline \multirow{3}{*}{ : } & \multirow{3}{*}{$\begin{array}{l}\text { Predominantly } \\
\text { gaining }\end{array}$} & \multirow{3}{*}{$\begin{array}{l}\text { Acid to } \\
\text { alkaline } \mathrm{pH}\end{array}$} & $\begin{array}{l}\text { Upwelling } \\
\text { ground water due to } \\
\text { high hydraulic } \\
\text { conductivity area }\end{array}$ & $\begin{array}{l}\text { Upwelling } \\
\text { hyporheic GDEs }\end{array}$ & \multirow{3}{*}{$\begin{array}{l}\text { Dominance of hypogean } \\
\text { species, in particular } \\
\text { stygobites and } \\
\text { stygophiles in } \\
\text { comparison with epigean } \\
\text { species }\end{array}$} & \multirow{3}{*}{$\begin{array}{l}\text { Stygobites : } \\
\text { Microcharon reginae; } \\
\text { Salentinella juberthiae; } \\
\text { Niphargus kochianus; } \\
\text { Niphargus } \\
\text { rhenorrhodanensis } \\
\text { Epigean: Gammarus } \\
\text { sp.; Candona sp.; }\end{array}$} \\
\hline & & & $\begin{array}{l}\text { Groundwater arrival at } \\
\text { a river elbow }\end{array}$ & $\begin{array}{l}\text { Meander hyporheic } \\
\text { GDEs }\end{array}$ & & \\
\hline & & & $\begin{array}{l}\text { Flushing of } \\
\text { groundwater due to } \\
\text { river bed morphology } \\
\text { (behind a dam) }\end{array}$ & $\begin{array}{l}\text { Dam hyporheic } \\
\text { GDEs }\end{array}$ & & \\
\hline \multicolumn{7}{|c|}{ Reach zone } \\
\hline & \multicolumn{3}{|c|}{ Characteristic } & & Indicative ecosociology & Indicative species \\
\hline & Hydrological & Chemical & $\begin{array}{l}\text { Geomorphological and } \\
\text { pedological }\end{array}$ & & & \\
\hline \multirow{7}{*}{ : } & \multirow{2}{*}{$\begin{array}{l}\text { Possibly } \\
\text { periodic } \\
\text { groundwater } \\
\text { discharge }\end{array}$} & \multirow{2}{*}{$\begin{array}{l}\text { Acid to } \\
\text { alkaline } \mathrm{pH}\end{array}$} & \multirow{2}{*}{$\begin{array}{l}\text { Lotic systems (brut } \\
\text { fluvisols and/or } \\
\text { gleysols) }\end{array}$} & \multirow[t]{2}{*}{ Lotic reach GDEs } & Glycerio-Sparganion & $\begin{array}{l}\text { Glyceria flutans, Berula } \\
\text { erecta, Nasturtium } \\
\text { offcinale }\end{array}$ \\
\hline & & & & & $\begin{array}{l}\text { Caricion bicolori- } \\
\text { atrofuscae }\end{array}$ & $\begin{array}{l}\text { Carex bicolor, Juncus } \\
\text { articus }\end{array}$ \\
\hline & \multirow{5}{*}{$\begin{array}{l}\text { Probably } \\
\text { permanent } \\
\text { groundwater } \\
\text { discharge }\end{array}$} & \multirow{3}{*}{$\begin{array}{l}\text { Neutral to } \\
\text { alkaline pH }\end{array}$} & \multirow{5}{*}{$\begin{array}{l}\text { Lentic systems (brut } \\
\text { fluvisols and/or } \\
\text { gleysols) }\end{array}$} & \multirow{3}{*}{$\begin{array}{l}\text { Alkaline lentic reach } \\
\text { GDEs }\end{array}$} & Potamion & $\begin{array}{l}\text { Potamogeton crispus, } \\
\text { Myriophyllum spicatum }\end{array}$ \\
\hline & & & & & Charion & $\begin{array}{l}\text { Chara fragilis, Nitella } \\
\text { batrachosperma }\end{array}$ \\
\hline & & & & & Phragmition & $\begin{array}{l}\text { Phragmites australis, } \\
\text { Equisetum fluviatile, } \\
\text { Typha latifolia, Typha } \\
\text { angustifolia }\end{array}$ \\
\hline & & \multirow{2}{*}{$\begin{array}{l}\text { Acid to } \\
\text { neutral } \mathrm{pH}\end{array}$} & & \multirow{2}{*}{$\begin{array}{l}\text { Circumneutral lentic } \\
\text { reach GDEs }\end{array}$} & Nymphaeion & $\begin{array}{l}\text { Nuphar lutea, } \\
\text { Ranunculus peltatus }\end{array}$ \\
\hline & & & & & Littorellion & $\begin{array}{l}\text { Littorella uniflora, } \\
\text { Sparganium } \\
\text { angustifolium }\end{array}$ \\
\hline
\end{tabular}

While $\mathrm{HZ}$ is mainly controlled by gradient and morphology, fauna is sensitive to the hydrological changes across the surface water bottom (see text); e.g. for reaches, plant associations are mainly determined by the chemical concentrations of water, whereas some plants (e.g. Phragmition alliances) may also be found in non-groundwater fed systems, e.g. water flowing on marls (after Bertrand et al. 2012a) 


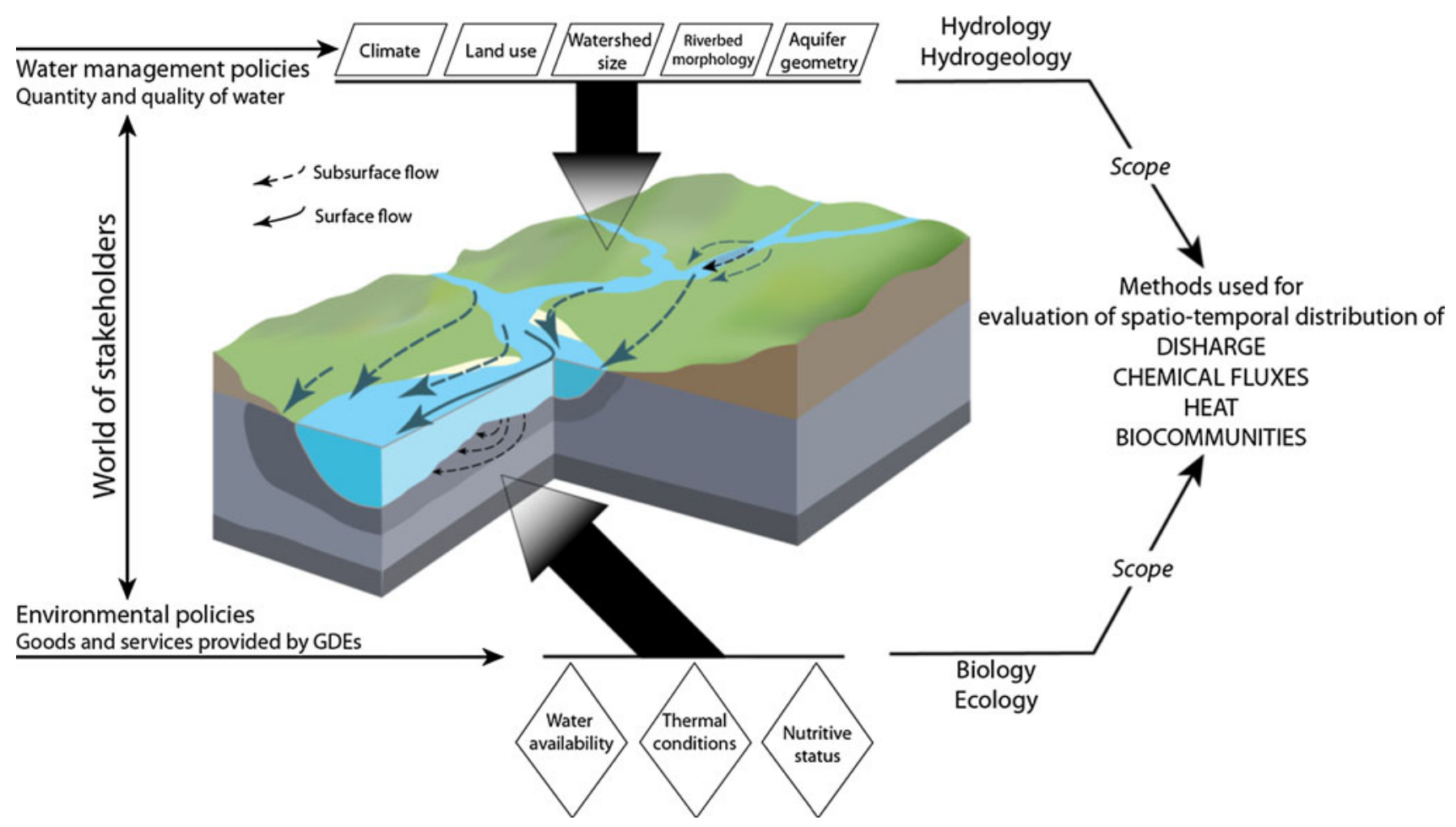

Fig. 2 Scope of the paper

1993; Younger 2007). Consequently, monitoring the spatio-temporal distribution of these physico-chemical and chemical indicators at the interfaces between SW and GW systems can be used to finely specify zones of interactions but also to identify their dynamics.

Thermal methods are based on heat (energy) propagation in the subsurface by flowing water (advection) and heat conduction via the fluid and the soil matrix. The advective flow strongly influences the temperature distribution in the mixing zone between groundwater and surface water. Hence, not only exchange zones but also water fluxes can be traced by measuring temperature distributions between the two systems (Constantz and Stonestrom 2003; Anderson 2005). Low-frequency signals, i.e. seasonal temperature variations, indicate mixing of groundwater sources of different ages and therefore usually cannot be employed in GW-SW exchange dynamics. In contrast, temperature variations on the basis of a few days are very useful in estimating water residence time and hyporheic exchange due to their uniqueness of frequency (Hoehn and Cirpka 2006; Young et al. 1999; Hatch et al. 2006; Keery et al. 2007; Vogt et al. 2010b, 2012). Time series analyses of temperature permit also to address the three-dimensional (3D) aspect of GW-SW interactions. Using temperature and hydraulic head data from a dense monitoring network, Silliman and Booth (1993), Constantz and Stonestrom (2003), Conant (2004) or Schmidt et al. (2007) analysed snapshots of vertical temperature profiles with a model assuming steady-state heat transfer. Such an approach makes it possible to compare simulated fluxes between $\mathrm{GW}$ and SW with fluxes inverted from fitting observed vertical temperature profiles to an analytical solution for 1D steadystate heat flow (Anibas et al. 2009) or using a fully integrated 3D surface/subsurface flow and heat transport model (Brookfield et al. 2009).

Similarly, different infiltration regimes can be traced by analysing diurnal and seasonal EC patterns after mathematical removal of seasonal components (Vogt et al. 2010a). This indicator moves virtually inseparably from the water and is relatively conservative (Cirpka et al. 2007). In contrast to diurnal fluctuations in temperature that are limited to the riverbed, fluctuations in EC can propagate several metres into the aquifer (Vogt et al. 2010a, b), and thus constitute an effective complement to temperature measurements (Osenbrück et al. 2013). Assuming a constant EC in the subsurface, GW-SW interactions can be evaluated through deconvolution of the EC time series in surface water (Cirpka et al. 2007; Osenbrück et al. 2013). As observed by Hatch et al. (2006), daily EC variations are predominantly distinct at low river water levels and high temperatures. In addition, in losing channels, diurnal photosynthetic processes responsible for $\mathrm{CO}_{2}$ fluctuations keep EC highest early in the morning and lowest in the afternoon which can be advantageously used.

A combination with DOC analysis would permit to precise which part of the landscape contributes to the 
Table 2 Summary matrix for each spatial scale identifying applicability environmental tracers

\begin{tabular}{|c|c|c|c|}
\hline Scale & Tracer & Applicability & Limitations \\
\hline \multirow[t]{3}{*}{ Watershed } & $\delta^{18} \mathrm{O}, \delta^{2} \mathrm{H}$ & $\begin{array}{l}\text { Separation of water sources; "new" and "old" water } \\
\text { contribution }\end{array}$ & $\begin{array}{l}\text { Event dependent, e.g. storm (certain } \\
\text { applications) }\end{array}$ \\
\hline & ${ }^{3} \mathrm{H}, \mathrm{CFC}, \mathrm{SF} 6$ & $\begin{array}{l}\text { Age and residence time estimation; identification of water } \\
\text { sources }\end{array}$ & $\begin{array}{l}\text { Existence of geological or anthropogenic } \\
\text { sources }\end{array}$ \\
\hline & ${ }^{222} \mathrm{Rn}$ & Estimates of residence time & Sorption, degassing \\
\hline \multirow[t]{6}{*}{ Reach } & Temperature & Simple, accessible, robust estimate of water fluxes, directions & Retarded, detrend may be needed \\
\hline & $\begin{array}{l}\text { Electrical } \\
\text { conductivity }\end{array}$ & and possibly sources & $\begin{array}{l}\text { Ion exchange, sharp redox barriers etc. may } \\
\text { alter the signal }\end{array}$ \\
\hline & $\begin{array}{l}\text { Invertebrates, } \\
\text { macrophytes }\end{array}$ & $\begin{array}{l}\text { Direct signal of GDE's status; identification of groundwater } \\
\text { discharge zones at GW-SW interfaces }\end{array}$ & $\begin{array}{l}\text { Cannot be used for estimation of flowpath or } \\
\text { residence time }\end{array}$ \\
\hline & $\mathrm{Cl}, \mathrm{Br}, \mathrm{Na}, \mathrm{Mg}$ & $\begin{array}{l}\text { Simple, accessible and reliable in places with distinctive } \\
\text { gradients }\end{array}$ & $\begin{array}{l}\text { Not always behave conservatively, affected } \\
\text { by residence time }\end{array}$ \\
\hline & $\mathrm{SiO}_{2}$ & $\begin{array}{l}\text { Simple, accessible, provides insight in shallow/deep flowpath } \\
\text { separation }\end{array}$ & \\
\hline & DOC & $\begin{array}{l}\text { Distinctive signatures of water origin in certain environments, } \\
\text { e.g. boreal }\end{array}$ & Highly reactive and biologically mediated \\
\hline \multirow[t]{2}{*}{$\begin{array}{l}\text { Hyporheic } \\
\text { zone }\end{array}$} & $\mathrm{NO}_{3}, \mathrm{NH}_{4}$ & $\begin{array}{l}\text { Vastly available in systems where human effects are high, } \\
\text { provide water sources and flowpath }\end{array}$ & Redox sensitive \\
\hline & $\begin{array}{c}\text { Dissolved } \\
\text { oxygen }\end{array}$ & $\begin{array}{l}\text { Useful where high gradients exist, indicates status of GDEs as a } \\
\text { habitat }\end{array}$ & $\begin{array}{l}\text { Chemically reactive redox control, } \\
\text { biologically and chemically mediated }\end{array}$ \\
\hline
\end{tabular}

stream discharge the most. Indeed, riparian soils serve as a major controller of surface water DOC in forested catchments (McGlynn and McDonnell 2003; Bishop et al. 2004; Laudon et al. 2004; Creed et al. 2008) which is mostly affected by transport mechanism and hydrological connectivity with aquifer (Laudon et al. 2011). Provided that the evolution of distribution of organic matter in a soil profile is known, the temporal DOC dynamics in a stream can be explained by the hydrological hot-moments and connectivity of organic rich layers within the aquifer and the stream (e.g. Lyon et al. 2011). Seasonal and punctual variability of DOC in surface flowing water can often be explained by the input from various DOC sources (e.g. wetlands) with variable hydrological connection to the reach (alternation of high flow, low flow periods, or punctual storm events) and therefore hint about water sources and flowpath in discharge areas. This was illustrated by Lyon et al. (2011), which took into account that a normal till soil profile is characterised by depleting DOC concentration with depth. Consequently, the temporal dynamics of DOC in streams have been found to be controlled by varying groundwater level, which activates different riparian soil horizons. Thus, by knowing potential DOC sources temporal DOC variations in streams provide information about water origin and its possible flowpath, i.e. whether groundwater/re-emerging surface water interacted with organic rich soil layers or landscape components. This has also implications for the biocenoses repartition in various reaches of a river continuum, as they are partly dependent on the organic matter availability.

The applicability of temperature and EC and their potential added value for GW-SW interactions studies is large due to their relatively low cost and the availability of rather simple developed analytical devices. It is more complicated with DOC though which temporal DOC evolution implies sampling and time-consuming laboratory work, making the continuous monitoring more difficult. An alternative way is in situ monitoring using specific probes for colored or fluorescent dissolved organic matter (CDOM/FDOM) to estimate DOC as these parameters are usually very well correlated (Spencer et al. 2012). However, the correlation depends on turbidity and local conditions and can change with season all the way to no correlation due to photobleaching (Kowalczuk et al. 2010). Although this possible limitation, Spencer et al. (2012) stressed that the potential of CDOM measurements using in situ instrumentation to improve spatial and temporal resolution of DOC fluxes and dynamics in future studies is considerable.

Water temperature, EC and organic matter content dynamics impact biocenoses located at the GW-SW interfaces, specifically macroinvertebrates. Therefore, similar to the macrophyte assessment approach, the impacts of GW-SW interaction types and further downscaling may be approached analysing their biodiversity, controlled by hyporheic flowpaths. 
Downscaling from reach scale to hyporheic scale: the macroinvertebrates biodiversity

Transition to a smaller scale investigation at a selected reach can be done using specific signatures of interaction type, and biological indicators such as macroinvertebrates can be highly supportive. The HZ is mainly inhabited by macroinvertebrates e.g. crustaceans and insect larvae, including stygobites (hypogean groundwater specialists), stygophiles (epigean animals pre-adapted for subsurface life) and stygoxenes (accidentally present in the subsurface). Some studies (e.g. Ward et al. 1998; Storey et al. 2004) revealed that sediment size and morphology of the river bed mainly affect hyporheic assemblages because exchange processes differ strongly between fine and coarse sediment stream areas. Accordingly, on a vertical axis, perpendicular to the channel bed, the fauna consists largely of oxyphilous (needing $\mathrm{O}_{2}$ ) species (mainly epigean) in superficial sediments, whereas deeper sediments harbour more hypoxia-tolerant species, which also tend to be stenotherm. This is peculiarly true for species or individuals that are not able to move, e.g. salmonids ova. Ova survival is dependent on complex GW-SW-metabolism interactions (Malcolm et al. 2004, 2009). It seems that equilibrium between surface water (providing oxygen) and groundwater contributions (providing thermal stability) needs to be reached. In some cases, such thermal stability may be ensured by shading riparian vegetation. On a horizontal axis, along the channel, the effect of river bed morphology is important. An example is zones behind dams, where groundwater seepage is favoured and biocenoses are dominated by hypoxia-tolerant species, particularly stygobites. This results in a mosaic of hydrological and ecological patches, which have unique faunal composition. This patchiness formed a basis for a qualitative model developed by Plénet et al. (1995); in downwelling zones, the subsurface is dominated by the epigean community and in upwelling zones by hypogean stygobites. Bertrand et al. (2012a) suggested some trends according to the patchiness model, which should be useful for identification of biogeochemical processes at GW-SW interfaces (Table 1). In upwelling conditions, stygobites (e.g. crustaceans such as Microcharon reginae, Salentinella juberthiae, Niphargus kochianus) tend to dominate over epigean species (e.g. Gammarus sp., Candona sp.) (Ward et al. 1998). Note these general trends have to be treated with care, as the mobility (e.g. active or passive) of the subsurface fauna is not yet fully understood.

The reach scale processes are often of importance in a variety of current socio-economic questions (Kløve et al. 2011b). Knowledge about exact water balance, flowpath and vulnerability is therefore valuable. At this scale, semiconservative parameters are useful and in combination with spatial distribution of macroinvertebrates delineate interaction zones and provide quantitative insights of the GW$\mathrm{SW}$ interaction. Such an approach permits to focus on zones with specific GW-SW interactions (thermal, chemical and organic matter exchanges) with ecological value requiring preservation. These $\mathrm{GW}-\mathrm{SW}$ interactions create various habitats with specific biogeochemical conditions. These can be then studied from the perspective of the HZ, to understand the low-scale ecological consequences of GW-SW exchanges.

The hyporheic scale: importance of biogeochemical interactions at the GW-SW interface

The metabolism of both producers and consumers is able to severely modify water chemistry at a very local scale, leading to local modification of the habitat structure especially through decrease of oxygen because of organic carbon catabolism in $\mathrm{GW}$ or conversely oxygenation of SW and organic matter influxes due to contact with atmosphere and proximity with reaches. Consistently, Fellows et al. (2001) demonstrated that $40-93 \%$ of the whole stream respiration occurred in the HZ. The magnitude of the impacts of biological processes on water chemistry will most likely depend on water residence time and thus on the GW-SW interaction dynamic at the local scale. Consequently, elements and parameters dependant on or influencing metabolism may be used to understand the biogeochemical reactor that constitutes the HZ. However, the extent of this biogeochemical reactor depends in turn on water and dissolved element fluxes as well as the structure of the substrate at the interface between SW and GW.

In this perspective, elements and parameters affected by redox conditions related to respiration and oxygenation processes, namely DO, organic carbon, ammonium, nitrate may delineate the relationships between $\mathrm{GW}$ and $\mathrm{SW}$ fluxes and biocenoses (Soulsby et al. 2009). For example, the ecological status of spawning sites has often been approached using DO as a measure of habitat quality (Malcolm et al. 2004). Soulsby et al. (2009) observed hyporheic exchanges in a salmon spawning stream in Scotland using two end-members: anoxic groundwater and oxygenated surface water. In this study, during the wet season, the GW upwelling maintained rather anoxic HZ, which was further oxygenated during hydrograph peaks, e.g. storms. In contrast, the dry season implied low GW level and thus promoted infiltration of SW with a high degree of DO saturation, conditions most suitable for salmon spawning. Stream discharge, groundwater fluxes, water temperature and sediments texture are the main controlling factors of DO saturation, DOC and redox sensitive indicators (Youngson et al. 2004; Malcolm et al. 
2009). Such seasonality of DO behaviour in the HZ means that long-term and high frequency monitoring is preferable when using DO as an indicator of GW-SW interplay (Malcolm et al. 2006). The absence of oxygen affects consumption of other electron donors along the redox ladder (denitrification, iron, manganese and sulphate reduction, methanogenesis), which can also be used, in particularly if local GW is proved to be significantly more reduced than SW, to identify $\mathrm{GW}-\mathrm{SW}$ biogeochemical interactions.

Accordingly, Krause et al. (2013) pointed out that high nitrate concentration differences (up to $60-70 \mathrm{mg} / \mathrm{l}$ in this case) between streambed and surface water spatially coincided with locations of upwelling inhibition due to the presence of confining peat or clay lenses in the HZ. Such trend is also viewable through reduced DO concentrations around flow-confining area provoked by longer residence times, favouring oxygen depletion and consequent denitrification. In addition, peat and clay strata provide more bio-available organic carbon and, hence, increase the availability of the electron donor required for denitrification (Hedin et al. 1998; Sobczak et al. 1998; Battin et al. 2003; Zarnetske et al. 2011a, b). By monitoring jointly DO and nitrate, evaluation of the effect of hyporheic flowpath on the HZ biogeochemistry, what is of concern to understand the effect of substrate texture change at a local scale over both hydrology and nutritive status of GW-SW interaction areas, is possible. In this perspective, the threshold effect should be taken into account as described e.g. by Valett et al. $(1994,1996)$ or Zarnetske et al. (2011a, b), who observed nitrate production along horizontal hyporheic exchange flowpaths to be correlated with increased hyporheic residence times until the residence time dependent depletion of DO caused denitrification. This process was then confirmed for the vertical axis by Krause et al. (2013) along a groundwater upwelling path because of the low conductive substrate locally present in the riverbed.

Therefore, it appears that monitoring reactive indicators at the local scale can help to map the spatial patchiness of GW-SW interaction and increase knowledge about hyporheic processes and biocenoses. This also permits to enrich the earlier suggested definitions and conceptual models of the HZ. By incorporating the information on the spatial distribution of aerobic/anaerobic biogeochemical processes and vertical gradients of nutrients, energy and oxygen, one extends the utility of the conceptual model for management of $\mathrm{HZ}$ processes and GDEs functioning as it was requested e.g. by Battin et al. (2003) and tend to evaluate the biogeochemical aspect of the Plénet et al.'s (1995) patchwork concept mentioned previously.

At the hyporheic scale, interchanging of downwelling and upwelling zones promotes biogeochemical and ecological richness of the entire surface water system.
Consequently, practical extension of these considerations is to propose solutions that consider GW-SW connectivity, mainly to locate where variability of riverbed morphology (e.g. meanders, dams) and sediment texture (variable conductivity) need to be increased (e.g. Kasahara et al. 2009) to favour biocenoses at the GW-SW interfaces.

Combining information from tracers and indicators across scales

Different tracers carry different types of information about water movement and changes in water chemistry along subsurface flowpaths and at the GW-SW interface (Kalbus et al. 2006; Cook 2012). Schematically, one can summarise the ecosystem dependence on GW as a dependence on water, energy and nutrient fluxes, which all being increasingly controlled by local processes or conversely decreasingly controlled by growing scale. In addition, being a highly dynamic environment, GDEs and HZ may experience effects of mixing between young river water, precipitation, soil water and older regional groundwater that are upwelling to enter the river. Therefore, this review addressed GDEs in an integrated perspective as nowadays requested by the environmental legislation, which finally requires combining information across scales (Fig. 3). The combined uses of various tracers and chemical indicators and the ecological assessment of the variability of SW-GW interaction across scales have recently been demonstrated to be useful. For instance, Caschetto et al. (2013) combined isotopic signatures $\left({ }^{18} \mathrm{O},{ }^{2} \mathrm{H}\right)$, as well as major ions in GW and $\mathrm{SW}$ and river discharge measurements from upstream to downstream, vertical assessment of physico-chemical parameters (EC, Eh, $\mathrm{pH}, T$ ) within the river bed, river discharge, and macroinvertebrates diversity and abundances in HZ This multi-scale and multi-parametric approach demonstrated that species response was controlled by the combination of three main stressors at the three scales conceptualised in the current review: nitrogen pollution (among others, depended on watershed scale input, and on local scale redox conditions controlled by substratum texture), anthropogenic modifications of river channel morphology affecting GW-SW fluxes (reach scale) and altered discharge regime (watershed scale channel diversion for recreational, agricultural and hydropower uses).

Although biological broad-scale patterns do not seem as obvious as hyporheic scale trends (Boulton et al. 1998), addressing the multiscale dimension of GW-SW interactions with a reciprocal philosophy, i.e. using macroinvertebrates to evaluate the variability of the interactions along the river continuum, may be also successfully envisaged in some cases. In this perspective, the use of copepod assemblages, the most diversified taxonomic group in GW, may allow describing surface-subsurface hydrological exchanges at the watershed scale (e.g. Ward and Voelz 


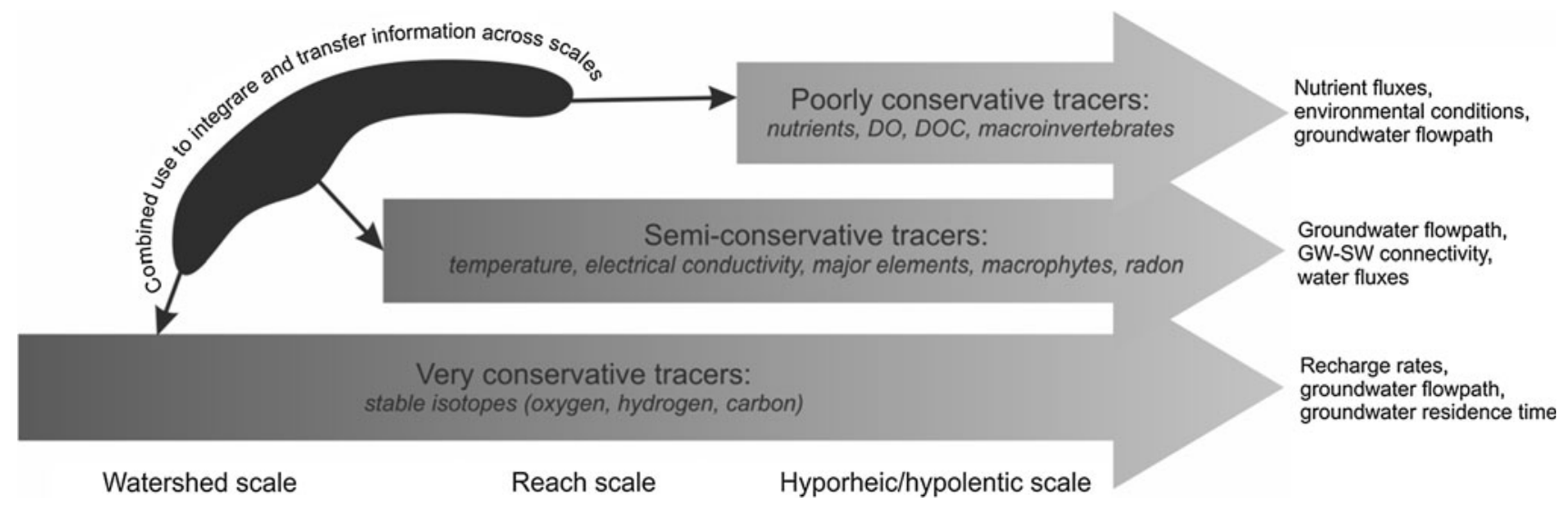

Fig. 3 Relationship between scale and principal applications of environmental tracers

1990; Di Lorenzo et al. 2013). Consistently, the various upwelling and downwelling GW areas may be identified through a spatial monitoring of stygobiotic and stygoxenes copepod diversity changes (Di Lorenzo et al. 2013). This approach is probably more adapted in pristine watershed, as anthropogenic impacts may alter the fauna distribution as mentioned previously. Nevertheless, other taxonomic groups can provide valuable information across scales in disturbed system, and especially oligochetes, which present variably pollution tolerant species. Therefore, oligochaete communities may help to assess in parallel the permeability of coarse habitats and the related water exchanges between surface and subsurface, and give an approximate measure of the metabolic activities in the sediments as well as the pollution incidence resulting from multiscale sources and processes (Lafont and Vivier 2006). Although this kind of approach is still rare, it can provide a valuable tool as it may help to both illustrate the patchy feature of GW-SW interactions and to control the types of interactions at the watershed scale. Such a patchiness, as mentioned previously is a key for ensuring the biodiversity at the catchment scale (Kasahara et al. 2009). Modern research goes towards a better process understanding of phenomena and links across different landscape elements and scales. Environmental tracers and water parameters are one of the major tools to assess the connectivity between these elements and their interaction. The feedback between landscape compartments comes into focus of work of several research groups around the world which have by now collected a decent historical time series and bridged the monitoring and modelling efforts including socio-economic and climate change scenarios (e.g. Grathwohl et al. 2013; Laudon et al. 2013). The eventual goal with all these efforts is to develop quantitative and conceptual understanding of catchment processes at scales from hyporheic to watershed in a changing environment.
As integrity of the GDEs is threatened by multifaceted pressures occurring at the three discussed scales, the pluridisciplinary approaches addressing watershed to $\mathrm{HZ}$ processes should be developed in the coming years. Remote sensing and integration of climate and land-use scenarios in multi-scale models (see e.g. Grathwohl et al. 2013) is a promising way for better management practices of GDEs. Further research is encouraged to continue using available experience of application of environmental tracers and indicators and shift towards their more combined usage, learn from interdisciplinary research strategies and contribute with new applications.

\section{Recommendations}

Based on the above proposed strategies linking environmental tracers and indicators, some recommendations may be done aiming to achieve goals of current groundwater legislations:

- Natural tracers and indicators studies that include biocenoses must become a part of national surface water and groundwater monitoring programmes, with associated data quality control. Available data on tracers and water indicators (e.g. $\mathrm{Cl}^{-}$, temperature, D.O.) and ecological assessment of water bodies from previous surveys may already be included in water monitoring programmes. A consistent and routinely performed interpretation of linkages between the tracer/ indicators sets and GDEs is required.

- Sampling strategies for national routine monitoring of environmental tracers should be revised in terms of the analyses, sampling methods, locations and frequency of monitoring involved and further standardised. Conventional methods of taking one sample per water body close to groundwater depth may be adequate to monitor 
changes at the watershed scale, but more intense monitoring programmes are required to identify GWSW interactions in areas of exceptional ecological importance.

- Modelling tools based on field studies must be developed to upscale or downscale available knowledge and predict the future fate and possible threats to GDEs. Combined use of several tracers and indicators and numerical modelling should lump highly complex biogeochemical processes in the $\mathrm{HZ}$ into a simple parameterisation, and could prove to be a useful tool in integrating information about GW-SW connectivity from natural tracers and indicators at the reach or catchment scale.

- The spatial distribution and temporal character of GDEs must be investigated and mapped on different administrative levels using various tracers/indicators and tracking historical changes.

- Combined use of several tracers and biological indicators is recommended to reveal GW-SW connectivity at different scales and can be useful in linking different parts of ecosystem and anthropogenic influences.

- Finally, from a management perspective, it must be borne in mind that many watersheds of socio-economic and ecological interest have been historically investigated from a hydrogeochemical and ecological point of view, and in many cases historical data are readily available. When correctly structured and used in a multidisciplinary approach, these data can provide a low-cost information base about GW-SW interactions in GDEs, which is a particular benefit in emerging or recession-struck countries.

Acknowledgments The work was carried out as part of the GENESIS project on groundwater systems (http://www.thegenesisproject. eu) financed by the European Commission 7FP contract 226536. The authors thank to four anonymous reviewers for their valuable remarks allowing the improvement of the manuscript.

\section{References}

Ala-aho P, Rossi PM, Kløve B (2013) Interaction of esker groundwater with headwater lakes and streams. J Hydrol 500:144-156

Alfaro C, Wallace M (1994) Origin and classification of springs and historical review with current applications. Environ Geol 24:112-124

Anderson MP (2005) Heat as a ground water tracer. Ground Water 43(6):951-968

Anibas C, Fleckenstein JH, Volze N, Buis K, Verhoeven R, Meire P, Batelaan O (2009) Transient or steady-state? Using vertical temperature profiles to quantify groundwater-surface water exchange. Hydrol Process 23:2165-2177

Baize D, Girard MC, Jabiol B, Rossignol JP, Eimberck M, Beaudou A (2009) Référentiel pédologique 2008 [2008 Pedological Referential]. Editions Quae, Versailles

Battin TJ, Kaplan LA, Newbold JD, Hendricks S (2003) A mixing model analysis of stream solute dynamics and the contribution of a hyporheic zone to ecosystem function. Freshw Biol 48:1-20
Bencala KE, McKnight DM, Zellwege GW (1987) Evaluation of natural tracers in an acidic and metal-rich stream. Water Resour Res 23:827-836

Bertrand G, Goldscheider N, Gobat J-M, Hunkeler D (2012a) Review: from multi-scale conceptualization of groundwater-dependent ecosystems to a classification system for management purposes. Hydrogeol J 20(1):5-25

Bertrand G, Masini J, Goldscheider N, Meeks J, Lavastre V, CelleJeanton H, Gobat JM, Hunkeler D (2012b) Determination of spatio-temporal variability of tree water uptake using stable isotopes $\left(\delta^{18} \mathrm{O} ; \delta^{2} \mathrm{H}\right)$ in an alluvial system supplied by a highaltitude watershed, Pfyn forest, Switzerland. Ecohydrology. doi:10.1002/eco.1347

Bishop K, Seibert J, Köhler S, Laudom H (2004) Resolving the Double Paradox of rapidly mobilized old water with highly variable responses in runoff chemistry. Hydrol Process 18:185-189

Boulton AJ, Findlay S, Marmonier P, Stanley EH, Valett HM (1998) The functional significance of the hyporheic zone in streams and rivers. Annu Rev Ecol Sys 29:1-59

Boulton AJ, Fenwick GD, Hancock PJ, Harvey MS (2008) Biodiversity, functional roles and ecosystem services of groundwater invertebrates. Invertebrate Syst 22:103-116

Boulton AJ, Datry T, Kasahara T, Mutz M, Stanford JA (2010) Ecology and management of the hyporheic zone: streamgroundwater interactions of running waters and their floodplains. J N Am Benthol Soc 29:26-40

Brookfield AE, Sudicky EA, Park YJ, Conant B (2009) Thermal transport modelling in a fully integrated surface/subsurface framework. Hydrol Process 23(15):2150-2164

Brunke M, Gonser T (1997) The ecological significance of exchange processes between rivers and groundwater. Freshw Biol 37:1-33

Caschetto M, Barbieri M, Galassi DMP, Mastrorillo L, Rusi S, Stoch F, Di Cioccio A, Petitta M (2013) Human alteration of groundwater-surface water interactions (Sagittario River, Central Italy): implication for flow regime, contaminant fate and invertebrate response. Environ Earth Sci. doi:10.1007/s12665013-2584-8

Cirpka OA, Fienen MN, Hofer M, Hoehn E, Tessarini A, Kipfer R, Kitanidis PK (2007) Analyzing bank filtration by deconvoluting time series of electric conductivity. Ground Water 45:318-328

Conant B Jr (2004) Delineating and quantifying ground water discharge zones using streambed temperatures. Ground Water 42(2):243-255

Constantz J, Stonestrom DA (2003) Heat as a tracer of water movement near streams. In: Stonestrom DA, Constantz J (eds) Heat as a tool for studying the movement of ground water near streams. US Geological Survey, US Geological Survey Circular 1260. US Geological Survey, Reston, pp 1-6

Cook PG (2012) Estimating groundwater discharge to rivers from river chemistry surveys. Hydrol Process. doi:10.1002/hyp.9493

Cook PG, Lamontagne S, Berhane D, Clark JF (2006) Quantifying groundwater discharge to Cockburn River, southeastern Australia, using dissolved gas tracers 222Rn and SF 6. Water Resour Res 42(10). doi:10.1029/2006WR004921

Council of the European Community (2000) Directive 2000/60/EU of the European Parliament and of the Council of 23 October 2000 establishing a framework for community action in the field of water policy. Off J Eur Communities L327/1 23.10.2000

Creed IF, Beall FD, Clair TA, Dillon PJ, Hesslein RH (2008) Predicting export of dissolved organic carbon from forested catchments in glaciated landscapes with shallow soils. Glob Biogeochem Cycles 22:GB4024. doi:10.1029/2008GB003294

Danielopol D, Gibert J, Griebler C, Gunatilaka A, Hahn HJ, Messana G, Notenboom J, Sket B (2004) The importance of incorporating 
ecological perspectives in groundwater management policy. Environ Conserv 31(3):185-189

Di Lorenzo T, Stoch F, Galassi DMP (2013) Incorporating the hyporheic zone within the river discontinuum: longitudinal patterns of subsurface copepod assemblages in an Alpine stream. Limnologica 43:288-296

Eamus D, Froend R, Loomes R, Hose G, Murray B (2006) A functional methodology for determining the groundwater regime needed to maintain the health of groundwater dependent vegetation. Aust J Bot 54:97-114

Engelhardt I, Piepenbrink M, Trauth N, Stadler S, Kludt C, Schulz M, Schuth C, Ternes T (2011) Comparison of tracer methods to quantify hydrodynamic exchange within the hyporheic zone. J Hydrol 400:255-266

EPA (2003) Guidance for the assessment of environmental factors (in accordance with the Environmental Protection Act 1986): consideration of subterranean fauna in groundwater and caves during environmental impact assessment in Western Australia, vol 54. Environmental Protection Authority, Brisbane

Fellows CS, Valett HM, Dahm CN (2001) Whole-stream metabolism in two montane streams: contribution of the hyporheic zone. Limnol Oceanogr 46:523-531

Gandy CJ, Smith JWN, Jarvis AP (2007) Attenuation of miningderived pollutants in the hyporheic zone: a review. Sci Total Environ 373:435-446

Garbey C, Thiébaut G, Muller S (2004) Morphological plasticity of a spreading aquatic macrophyte, Ranunculus peltatus, in response to environmental variables. Plant Ecol 173(1):125-137

Grathwohl P, Ruegner H, Wöhling T, Osenbrück K, Schwientek M, Gayler S, Wollschläger U, Selle B, Pause M, Delfs JO, Grzeschik M, Weller U, Ivanov M, Cirpka OA, Maier U, Kuch B, Nowak W, Wulfmeyer V, Warrach-Sagi K, Streck T, Attinger S, Bilke L, Dietrich P, Fleckenstein JH, Kalbacher T, Kolditz O, Rink K, Samaniego L, Vogel HJ, Werban U, Teutsch G (2013) Catchments as reactors: a comprehensive approach for water fluxes and solute turn-over. Environ Earth Sci 69(2):317-333. doi:10.1007/s12665-013-2281-7

Grosbois C, Négrel Ph, Fouillac C, Grimaud D (2001) An overview of dissolved and suspended matter fluxes in the Loire river basin: natural and anthropogenic inputs. Aqueous Geochem 7:81-105

GSchV (1998) Gewässerschutzverordnung vom 28. Oktober 1998 (GSchV, SR 814.201) [Swiss Water Protection Ordinance]. Swiss Federal Law, Bern

Guggenmoss MR, Daughney CJ, Jackson BM, Morgenstern U (2011) Regional-scale identification of GW-SW interaction using hydrochemistry and multivariate statistical methods, Wairarapa Valley, New Zealand. Hydrol Earth Syst Sci 15:3383-3398

Güler C, Thyne GD (2004) Delineation of hydrochemical facies distribution in a regional groundwater system by means of fuzzy c-means clustering. Water Resour Res 40:1-11

Hahn HJ (2006) The GW-fauna-index: a first approach to a quantitative ecological assessment of groundwater habitats. Limnologia 36(2):119-139

Hancock PJ (2002) Human impacts on the stream-groundwater exchange zone. Environ Manag 29(6):763-781

Haslam SM (1987) River plants of western Europe. Cambridge University Press, Cambridge

Hatch CE, Fischer AT, Revenaugh JS, Constantz J, Ruehl C (2006) Quantifying surface water-groundwater interactions using time series analysis of streambed thermal records: method development. Water Resour Res 42:W10410. doi:10.1029/2005WR004787

Hedin LO, von Fischer JC, Ostrom NE, Kennedy BP, Brown MG, Robertson GP (1998) Thermodynamic constraints on nitrogen transformations and other biogeochemical processes at soilstream interfaces. Ecology 79:684-703
Hoehn E, Cirpka OA (2006) Assessing residence times of hyporheic ground water in two alluvial flood plains of the Southern Alps using water temperature and tracers. Hydrol Earth Syst Sci 10(4):553-563

Hoehn E, von Gunten HR (1989) Radon in groundwater: a tool to assess infiltration from surface waters to aquifers. Water Resour Res 25(8):1795-1803

Hooper RP, Shoemaker CA (1986) A comparison of chemical and isotopic hydrograph separation. Water Resour Res 22:14441454

Kalbus E, Reinstorf F, Schirmer M (2006) Measuring methods for groundwater-surface water interactions: a review. Hydrol Earth Syst Sci 10:873-887

Kasahara T, Datry T, Mutz M, Boulton A (2009) Treating causes not symptoms: restoration of surface-groundwater interactions in rivers. Mar Freshw Biol 60(9):976-981

Keery J, Binley A, Crook N, Smith JWN (2007) Temporal and spatial variability of groundwater-surface water fluxes: development and application of an analytical method using temperature time series. J Hydrol 336(1-2):1-16

Kendall C, Caldwell EA (1998) Fundamentals of isotope geochemistry. In: Kendall C, McDonnell JJ (eds) Isotope tracers in catchment hydrology. Elsevier Science BV, London, pp 51-86

Kløve B, Ala-aho P, Bertrand G, Boukalova Z, Ertürk A, Goldscheider N, Ilmonen J, Karakaya N, Kupfersberger H, Kvœrner J, Lundberg A, Mileusnić M, Moszczynska A, Muotka T, Preda E, Rossi P, Siergieiev D, Šimek J, Wachniew P, Widerlund A (2011a) Groundwater Dependent Ecosystems: part I-hydroecological status and trends. Environ Sci Policy 14(7):770-781

Kløve B, Ala-aho P, Allan A, Bertrand G, Druzynska E, Ertürk A, Goldscheider N, Henry S, Karakaya N, Koundouri P, Kvœrner J, Lundberg A, Muotka T, Preda E, Pulido-Velázquez M, Schipper P (2011b) Groundwater dependent ecosystems: part II-Ecosystem services and management in Europe under risk of climate change and land-use intensification. Environ Sci Policy 14(7):782-793

Kløve B, Bertachi C, Bertrand G, Gurdak J, Kupfersberger H, Kvoerner J, Muotka T, Preda E, Pulido-Velazquez M, Wachniew $P$ (in press) Climate change impacts on groundwater and dependent ecosystems. Invitation for a special issue "Climatic change impact on water: overcoming data and science gaps". J Hydrol. doi:10.1016/j.jhydrol.2013.06.037

Kowalczuk P, Zablocka M, Sagan S, Kulinski K (2010) Fluorescence measured in situ as a proxy of CDOM absorption and DOC concentration in the Baltic Sea. Oceanologia 52(3):431-471

Krause S, Tecklenburg C, Munz M, Naden E (2013) Streambed nitrogen cycling beyond the hyporheic zone: flow controls on horizontal patterns and depth distribution of nitrate and dissolved oxygen in the upwelling groundwater of a lowland river. J Geophys Res Biogeosci 118:54-67. doi:10.1029/2012JG 002122

Kumar M, Ramanathan A, Keshari AK (2009) Understanding the extent of interactions between groundwater and surface water through major ion chemistry and multivariate statistical techniques. Hydrol Process 23:297-310

Kværner J, Snilsberg P (2008) The Romeriksporten railway tunneldrainage effects on peatlands in the lake Northern Puttjern area. Eng Geol 101:75-88

Lafont M, Vivier A (2006) Oligochaete assemblages in the hyporheic zone and coarse surface sediments: their importance for understanding of ecological functioning of watercourses. Hydrobiologia $564: 171-181$

Laudon H, Slaymaker O (1997) Hydrograph separation using stable isotopes, silica and electrical conductivity: an alpine example. J Hydrol 201:82-101 
Laudon H, Köhler S, Buffam I (2004) Seasonal TOC export from seven boreal catchments in northern Sweden. Aquat Sci 66(2):223-230

Laudon H, Berggren M, Agren A, Buffam I, Bishop K, Grabs T, Jansson M, Köhler S (2011) Patterns and dynamics of dissolved organic carbon (DOC) in boreal streams: the role of processes, connectivity, and scaling. Ecosystems 14:880-893

Laudon H, Taberman I, Ågren A, Futter M, Ottosson-Löfvenius M, Bishop K (2013) The Krycklan Catchment Study - a flagship infrastructure for hydrology, biogeochemistry, and climate research in the boreal landscape. Water Resour Res 49:1-5. doi:10.1002/wrcr.20520

Leahy PP, Rosenshein JS, Knopman DS (1990) Implementation plan for the national water-quality assessment program. USGS OpenFile Report 90-174, Denver, USA

Lyon SW, Grabs T, Laudon H, Bishop KH, Seibert J (2011) Variability of groundwater levels and total organic carbon (TOC) in the riparian zone of a boreal catchment. J Geophys Res-Biogeo 116:G01020. doi:10.1029/2010JG001452

Malcolm IA, Soulsby C, Youngson AF, Hannah DM, McLaren IS, Thorne A (2004) Hydrological influences on hyporheic water quality: implications for salmon survival. Hydrol Process 18:1543-1560

Malcolm IA, Soulsby C, Youngson AF (2006) High frequency logging technologies reveal state dependant hyporheic process dynamics: implications for hydroecological studies. Hydrol Process 20:615-622

Malcolm IA, Soulsby C, Youngson AF, Tetzlaff D (2009) Fine scale variability of hyporheic hydrochemistry in salmon spawning gravels with contrasting GW-SW interactions. Hydrogeol J 17(1):161-174

McCabe DJ (2010) Rivers and streams: life in flowing water. Nat Educ Knowl 1(12):4

McGlynn B, McDonnell J (2003) Quantifying the relative contributions of riparian and hillslope zones to catchment runoff. Water Resour Res 39(11):1310. doi:10.1029/2003WR002091

McNeil VH, Cox ME, Preda M (2005) Assessment of chemical water types and their spatial variation using multi-stage cluster analysis, Queensland, Australia. J Hydrol 310:181-200

Meybeck M (1998) Man and river interface: multiple impacts on water and particulates chemistry illustrated in the Seine river. Hydrobiologia 373(374):1-20

Mohammed N, Celle-Jeanton H, Huneau F, Le Coustumer P, Lavastre V, Bertrand G, Charrier G, Clauzet ML (2014) Isotopic and geochemical identification of main groundwater supply sources to an alluvial aquifer, the Allier River valley (France). J Hydrol 508:181-196. doi:10.1016/j.jhydrol.2013.10.051

Négrel P, Petelet-Giraud E, Barbier J, Gautier E (2003) Surface water groundwater interactions in an alluvial plain: chemical and isotopic systematic. J Hydrol 277:248-267

Nimick DA, Gammons CH, Parker SR (2011) Diel biogeochemical processes and their effect on the aqueous chemistry of streams: a review. Chem Geol 283:3-17

Osenbrück K, Wöhling T, Lemke D, Rohrbach N, Schwientek M, Leven C, Castillo Alvarez C, Taubald H, Cirpka OA (2013) Assessing hyporheic exchange and associated travel times by hydraulic, chemical, and isotopic monitoring at the Steinlach Test Site, Germany. Environ Earth Sci 69:359-372

Pacioni E, Petitta M, Burri E, Fanelli M, Mazzeo P, Ruggieri F (2010) Influence of surface/groundwater interaction on pollution by pesticides in farmlands of the Fucino Plain, Central Italy. Environ Earth Sci 61:201-216

Petalas CP (2013) The impact of gravel extraction on groundwater dependent wetlands and lakes in the Boreal Plains, Canada. Environ Earth Sci 70:439-452

Plénet S, Gibert J, Marmonnier P (1995) Biotic and abiotic interactions between surface and interstitial systems in rivers. Ecography 18:296-309
Renöfält B, Jansson R, Nilsson C (2010) Effects of hydropower generation and opportunities for environmental flow management in Swedish riverine ecosystems. Freshw Biol 55(1):49-67

Rossi PM, Ala-aho P, Ronkanen A, Kløve B (2012) Groundwatersurface water interaction between an esker aquifer and a drained fen. J Hydrol 432-433:52-60

Schmidt C, Conant B Jr, Bayer-Raich M, Schirmer M (2007) Evaluation and field-scale application of an analytical method to quantify groundwater discharge using mapped streambed temperatures. J Hydrol 347:292-307

Schmidt A, Gibson JJ, Santos IR, Schubert M, Tattrie K, Weiss H (2010) The contribution of groundwater discharge to the overall water budget of two typical Boreal lakes in Alberta/Canada estimated from a radon mass balance. Hydrol Earth Syst Sci 14:79-89

Seddon B (1972) Aquatic macrophytes as limnological indicators. Freshw Biol 2(2):107-130

Shimada J, Kayane I, Shimano Y, Taniguchi (1993) Use of several environmental tracers to detect the surface-subsurface water interaction in an alluvial fan. In: Peters NE, Hoehn E, Leibundgut C, Tase N, Walling DE (eds) Tracers in hydrology, vol 215. Proceedings of the Yokohama Symposium, Yokohama, 1993

Silliman SE, Booth DF (1993) Analysis of time-series measurements of sediment temperature for identification of gaining vs. loosing portions of Juday Creek, Indiana. J Hydrol 146:131-148

Smerdon BD, Mendoza CA, Devito KJ (2012) The impact of gravel extraction on groundwater dependent wetlands and lakes in the Boreal Plains, Canada. Environ Earth Sci 67(5):1249-1259

Sobczak WV, Hedin LO, Klug MJ (1998) Relationships between bacterial productivity and organic carbon at a soil-stream interface. Hydrobiologia 386:45-53

Soulsby C, Malcolm IA, Youngson AF (2001) Hydrochemistry of the hyporheic zone in salmon spawning gravels: a preliminary assessment in a degraded agricultural stream. Regul Rivers Res Manag 17(6):651-665

Soulsby C, Malcolm I, Tetzlaff D, Youngson AF (2009) Seasonal and inter-annual variability in hyporheic water quality revealed by continuous monitoring in a salmon spawning stream. River Res Appl 25(10):1304-1319

Spencer RGM, Butler KD, Aiken GR (2012) Dissolved organic carbon and chromophoric dissolved organic matter properties of rivers in the USA. J Geophys Res 117:G03001. doi:10.1029/ 2011JG001928

Stewart MK, Mehlhorn J, Elliott S (2007) Hydrometric and natural tracer (oxygen-18, silica, tritium and sulphur hexafluoride) evidence for a dominant groundwater contribution to Pukemanga Stream, New Zealand. Hydrol Process 21:3340-3356

Stonedahl SH, Harvey JW, Wörman A, Salehin M, Packman AI (2010) A multiscale model for integrating hyporheic exchange from ripples to meanders. Water Resour Res 46:W12539

Storey RG, Williams DD, Fulthorpe RR (2004) Nitrogen processing in the hyporheic zone of a pastoral stream. Biogeochemistry 69(3):285-313

Taylor CB, Wilson DD, Brown LJ, Stewart MK, Burden RJ, Brailsford GW (1989) Sources and flow of North Canterbury Plains groundwater, New Zealand. J Hydrol 106:311-340

Thyne GD, Güler C, Poeter E (2004) Sequential analysis of hydrochemical data for watershed characterization. Ground Water 42:711-723

Tomlinson M, Boulton A (2008) Subsurface groundwater dependent ecosystems: a review of their biodiversity, ecological processes and ecosystem services. Waterlines Occasional Paper 8:1-77

Toth J (1963) A theoretical analysis of groundwater flow in small drainage basins. J Geophys Res 68:4795-4812

Valett HM, Fisher SG, Grimm NB, Camill P (1994) Vertical hydrologic exchange and ecological stability of a desert stream ecosystem. Ecology 75:548-560 
Valett HM, Morrice JA, Dahm CN, Campana ME (1996) Parent lithology, surface-groundwater exchange, and nitrate retention in headwater streams. Limnol Oceanogr 41:333-345

Vogt T, Hoehn E, Schneider P, Freund A, Schirmer M, Cirpka OA (2010a) Fluctuations of electrical conductivity as a natural tracer for bank filtration in a losing stream. Adv Water Resour 33:1296-1308

Vogt T, Schneider P, Hahn-Woernle L, Cirpka OA (2010b) Estimation of seepage rates in a losing stream by means of fiberoptic high-resolution vertical temperature profiling. J Hydrol 380:154-164

Vogt T, Schirmer M, Cirpka OA (2012) Investigating riparian groundwater flow close to a losing river using diurnal temperature oscillations at high vertical resolution. Hydrol Earth Syst Sci 16:473-487

Ward JV, Voelz NJ (1990) Gradient analysis of interstitial meiofauna along a longitudinal stream profile. Stygologia 5:93-99

Ward JW, Bretschko G, Brunke M, Danielopol D, Gibert J, Gonser T, Hildrew AG (1998) The boundaries of river systems: the metazoan perspective. Freshw Biol 40:531-569
Winter TC (2001) Ground water and surface water: the linkage tightens, but challenges remain. Hydrol Process 15:3605-3606

Winter TC, Harvey JW, Franke OL, Alley WM (1998) Ground water and surface water; a single resource. US Geological Survey Circular 1139. USGS, Denver, 0364-6017

Young PC, Pedregal DJ, Tych W (1999) Dynamic harmonic regression. J Forecast 18(6):369-394

Younger P (2007) Groundwater in the environment: an introduction. Blackwell Publishing, UK

Youngson AF, Malcolm IA, Thorley JL, Bacon PJ, Soulsby C (2004) Long-residence groundwater effects on incubating salmonid eggs: low hyporheic oxygen impairs embryo development. Can J Fish Aquat Sci 61:2278-2287

Zarnetske JP, Haggerty R, Wondzell SM, Baker MA (2011a) Dynamics of nitrate production and removal as a function of residence time in the hyporheic zone. J Geophys Res 116:G01025

Zarnetske JP, Haggerty R, Wondzell SM, Baker MA (2011b) Labile dissolved organic carbon supply limits hyporheic denitrification. J Geophys Res 116:G04036 